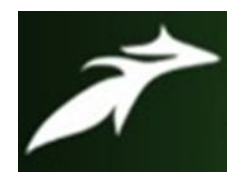

J.Sakthi et al, International Journal of Advances in Agricultural Science and Technology,

Vol.8 Issue.8, August-2021, pg. 110-114

ISSN: 2348-1358

Impact Factor: 6.057

NAAS Rating: 3.77

\title{
Effect of Foliar Application of Water-Soluble Fertilizers for Yield and Economics of Rice Fallow Blackgram (Vigna mungo (L). Hepper)
}

\author{
J.Sakthi*; K. Kaleeswari; Karthika S Kumar; K. Nirosha; K.Ramya; R.Kumar \\ Department of Agronomy, The Indian Agriculture College, Radhapuram, Tirunelveli- 627111 \\ "Corresponding author's email: gunasakthi01@gmail.com \\ DOI: 10.47856/ijaast.2021.v08i8.012
}

\begin{abstract}
Field experiment was conducted at farmer field in kadukkarai village, Kanyakumari during February 2021 - April 2021 to evaluate the Effect of foliar nutrition for maximizing the productivity of rice fallow blackgram (Vigna mungo (L). Hepper). Nine treatments were tested in randomized block design with three replications. Among the treatments, application of RDF + Foliar spray of $1 \%$ 19:19:19 on 15 DAS + Foliar spray of 1\% 12: 61:0 30 DAS + Foliar spray of 1\% 13:0:45 on 45 DAS significantly recorded highest grain yield $\left(723 \mathrm{~kg} \mathrm{ha}^{-1}\right)$ and haulm yield $\left(2320 \mathrm{~kg} \mathrm{ha}^{-1}\right)$. However, the highest gross return (Rs.53, 955), net return (Rs.41, 305) and BC ratio (3.27) were recorded the foliar spray of 1\% 19:19:19 on 15 DAS + Foliar spray of 1\% 12: 61:0 30 DAS + Foliar spray of 1\% 13:0:45 on 45 DAS.
\end{abstract}

Keywords: Black gram, foliar spray, Grain yield and net return.

\section{Introduction}

Black gram is one of the important pulse crops grown throughout India. It is consumed in the form of 'dal' (whole or split, husked and un-husked) or perched. It is used as nutritive fooder specially for milch animals. It is also green manuring crop. High values of lysine make urdbean an excellent complement to rice in terms of balanced human nutrition. In India pulses are cultivated in an area of 52.79 million hectares with a production and productivity of 34.92 million tonnes and $662 \mathrm{~kg} \mathrm{ha} \mathrm{ha}^{-1}$ respectively (INDIASTAT, 2018). In Tamil Nadu rice fallow pulses contributes 40-50\% of total pulses production in which blackgram occupies a major share. The productivity of rice fallow blackgram is always far below than its normal cultivation (Sasikala et al., 2014).The main reasons for low productivity are poor plant population, poor nutrient and moisture stress under critical stages. Generally, rice fallow blackgram sowing will be carried out a week before harvest of rice crop and fertilizer incorporation becomes impossible. Under these circumstances, foliar application of nutrients 


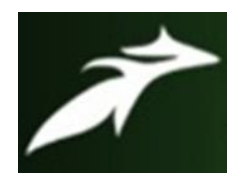

J.Sakthi et al, International Journal of Advances in Agricultural Science and Technology, Vol.8 Issue.8, August-2021, pg. 110-114

ISSN: 2348-1358

Impact Factor: 6.057

NAAS Rating: 3.77

would be more appropriate, efficient and economical than soil application. (Balusamy and Meyyazhagan, 2000). Hence, proper nutrient management is an important factor to be considered for sustaining pulse productivity.

\section{Material and Methods}

A field experiment was conducted at farmer field in kadukkarai village, Kanyakumari during February 2021 - April 2021 to evaluate the Effect of foliar nutrition for maximizing the productivity of rice fallow blackgram (Vigna mungo (L). Hepper). Blackgram VBN 3 was used as the test variety. The experiment was laid out in Randomized block design (RBD) with three replications. It consisted of nine treatments viz., T1- Control,T2- Foliar spray of 0.5\% 19:19:19 on 15, 30 and 45 DAS, T3Foliar spray of 0.5\% 12: 61:0 on 15, 30 and 45 DAS, T4- Foliar spray of 0.5\% 13:0:45 on 15, 30 and 45 DAS, T5- Foliar spray of 0.5\% 19:19:19 on 15 DAS + Foliar spray of 0.5\% 12: 61:0 30 DAS + Foliar spray of 0.5\% 13:0:45 on 45 DAS, T6- Foliar spray of 1\% 19:19:19 on 15, 30 and 45 DAS, T7- Foliar spray of 1\% 12: 61:0 on 15, 30 and 45 DAS, T8- Foliar spray of 1\% 13:0:45 on 15, 30 and 45 DAS, T9- Foliar spray of 1\% 19:19:19 on 15 DAS + Foliar spray of 1\% 12: 61:0 30 DAS + Foliar spray of 1\% 13:0:45 on 45 DAS. Blackgram variety VBN 3 was sown under rice fallow condition. Water soluble fertilizers were applied as per the treatment schedule. No. of pod plant ${ }^{-1}$, No. of seeds pod $^{-1}$, seed yield and economics of blackgram were recorded.

\section{Results and Discussion}

\section{Yield Attributes}

The various yield attributing characters of rice fallow blackgram significantly differ due to foliar spray of different combination of water soluble fertilizers (Table 1).

In the present study, adoption of different foliar application practices significantly influenced the yield attributes of rice fallow blackgram. Foliar application of 1\% 19:19:19 on 15 DAS + Foliar spray of 1\% 12: 61:0 30 DAS + Foliar spray of 1\% 13:0:45 on 45 DAS recorded highest values for yield attributing characters viz., number of pods per plant(33.6), number of seeds per pod(6.01) and 100 seed weight $(5.53 \mathrm{~g})$ than the other foliar spray treatments. Foliar spray thrice during vegetative stage, flowering stage and pod filling stage might be due to enhanced photosynthetic activity and higher uptake of nutrients and thereby increased plant dry matter production in the pod setting phase which 


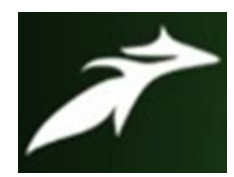

J.Sakthi et al, International Journal of Advances in Agricultural Science and Technology,

Vol.8 Issue.8, August-2021, pg. 110-114

ISSN: 2348-1358

Impact Factor: 6.057

NAAS Rating: 3.77

might have improved the pod development and number of pods per plant. Earlier findings by Sharifi et al., (2018) and Jahid Ahmad et al., (2019) agreed with the present findings.

\section{Yield}

Adoption of various foliar nutrition treatments significantly influenced the seed yield of rice fallow blackgram, which was ranged from 403-723 $\mathrm{kg} \mathrm{ha}^{-1}$ (Table 2). In the case foliar application of 1\% 19:19:19 on 15 DAS + Foliar spray of 1\% 12: 61:0 30 DAS + Foliar spray of 1\% 13:0:45 on 45 DAS recorded significantly higher grain $\left(723 \mathrm{~kg} \mathrm{ha}^{-1}\right)$ and haulm yield $\left(2320 \mathrm{~kg} \mathrm{ha}^{-1}\right)$ of rice fallow blackgram as compared to other treatments. Balanced growth habit, induced more flower and fruiting body production with timely supply of nutrients through foliar spray, might have reduced shedding of flowers and fruits, which led to a positive source-sink gradient of photosynthates translocation due to growth regulator on the other hand. The highest seed yield obtained in treatments might be due to higher nutrient mobility uptake and provided with all essential elements needed on time. These favourable effects might have attributed for higher yield of blackgram under the foliar spray of major nutrients. This finding is in line with the results of Takankhar et al., (2017) and Jadhav et al., (2017).

Table 1. Effect of foliar nutrition on the yield attributes of rice fallow blackgram

\begin{tabular}{|c|c|c|c|c|}
\hline T.no & Treatments & $\begin{array}{l}\text { No. of } \\
\text { pods per } \\
\text { plant }\end{array}$ & $\begin{array}{l}\text { No. of } \\
\text { seeds } \\
\text { per pod }\end{array}$ & $\begin{array}{l}100 \text { seed } \\
\text { weight } \\
\text { (g) }\end{array}$ \\
\hline T1 & Control & 19.4 & 4.82 & 4.58 \\
\hline $\mathrm{T} 2$ & Foliar spray of $0.5 \% 19: 19: 19$ on 15,30 and 45 DAS & 22.4 & 5.02 & 4.72 \\
\hline T3 & Foliar spray of $0.5 \% 12: 61: 0$ on 15,30 and 45 DAS & 21.9 & 5 & 4.61 \\
\hline T4 & Foliar spray of $0.5 \% 13: 0: 45$ on 15,30 and 45 DAS & 24.9 & 5.2 & 4.76 \\
\hline T5 & $\begin{array}{l}\text { Foliar spray of } 0.5 \% \text { 19:19:19 on } 15 \text { DAS + Foliar spray of } 0.5 \% \\
12: 61: 030 \text { DAS + Foliar spray of } 0.5 \% 13: 0: 45 \text { on } 45 \text { DAS }\end{array}$ & 29.3 & 5.67 & 4.87 \\
\hline T6 & Foliar spray of $1 \% 19: 19: 19$ on 15,30 and 45 DAS & 26.2 & 5.27 & 4.8 \\
\hline $\mathrm{T7}$ & Foliar spray of $1 \% 12: 61: 0$ on 15,30 and 45 DAS & 25.8 & 5.22 & 4.77 \\
\hline T8 & Foliar spray of $1 \% 13: 0: 45$ on 15,30 and 45 DAS & 28.9 & 5.56 & 4.85 \\
\hline T9 & $\begin{array}{l}\text { Foliar spray of } 1 \% 19: 19: 19 \text { on } 15 \text { DAS + Foliar spray of } 1 \% \\
12: 61: 030 \text { DAS + Foliar spray of } 1 \% 13: 0: 45 \text { on } 45 \text { DAS }\end{array}$ & 33.6 & 6.01 & 5.03 \\
\hline \multirow{2}{*}{\multicolumn{2}{|c|}{$\begin{array}{rr}\text { SEd } \\
\mathrm{CD}(\mathrm{P}=0.05)\end{array}$}} & 1.2 & 0.06 & 0.23 \\
\hline & & 2.4 & 0.13 & NS \\
\hline
\end{tabular}




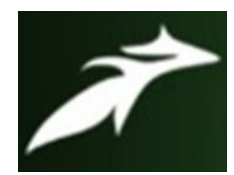

J.Sakthi et al, International Journal of Advances in Agricultural Science and Technology,

Vol.8 Issue.8, August-2021, pg. 110-114

ISSN: 2348-1358

Impact Factor: 6.057

NAAS Rating: 3.77

Table.2. Effect of foliar nutrition on seed yield and haulm yield ( $\left.\mathrm{kg} \mathrm{ha}^{-1}\right)$ of rice fallow blackgram

\begin{tabular}{|c|l|c|c|}
\hline T.no. & \multicolumn{1}{|c|}{ Treatments } & $\begin{array}{c}\text { Seed yield } \\
\left.\mathbf{k g ~ h a}^{-1}\right)\end{array}$ & $\begin{array}{c}\text { Haulm yield } \\
\left.\mathbf{( k g ~ h a}^{-1}\right)\end{array}$ \\
\hline T1 & Control & 403 & 1291 \\
\hline T2 & Foliar spray of 0.5\% 19:19:19 on 15, 30 and 45 DAS & 470 & 1517 \\
\hline T3 & Foliar spray of 0.5\% 12: 61:0 on 15, 30 and 45 DAS & 455 & 1490 \\
\hline T4 & Foliar spray of 0.5\% 13:0:45 on 15, 30 and 45 DAS & 520 & 1676 \\
\hline T5 & $\begin{array}{l}\text { Foliar spray of 0.5\% 19:19:19 on 15 DAS + Foliar spray of 0.5\% } \\
\text { 12: 61:0 30 DAS + Foliar spray of 0.5\% 13:0:45 on 45 DAS }\end{array}$ & 637 & 2062 \\
\hline T6 & Foliar spray of 1\% 19:19:19 on 15, 30 and 45 DAS & 561 & 1816 \\
\hline T7 & Foliar spray of 1\% 12: 61:0 on 15, 30 and 45 DAS & 550 & 1775 \\
\hline T8 & Foliar spray of 1\% 13:0:45 on 15, 30 and 45 DAS & 608 & 1969 \\
\hline T9 & $\begin{array}{l}\text { Foliar spray of 1\% 19:19:19 on 15 DAS + Foliar spray of 1\% } \\
\text { 12: 61:0 30 DAS + Foliar spray of 1\% 13:0:45 on 45 DAS }\end{array}$ & 2320 \\
\hline & & 21 & 66 \\
\hline
\end{tabular}

\section{Economics}

The ultimate aim of addition of any input, whether it is cash or farm produced input, depends on how far it is profitable. Higher crop productivity with lesser cost of cultivation could result in better economic parameters like net return and $\mathrm{B}$ : $\mathrm{C}$ ratio (Table 3). The cost of cultivation, gross return, net return and $\mathrm{B}$ : $\mathrm{C}$ ratio was worked out for various treatments adopted in rice fallow blackgram. Cost of cultivation of various treatments was ranged between ₹ 9450 and ₹ $13050 \mathrm{ha}^{-1}$. This difference in cost of cultivation between treatments was due to the use of different nutrients as foliar spray. The highest net income (₹ 41,305) and B: C ratio (3.27) was found with the foliar application of 1\% 19:19:19 on 15 DAS + Foliar spray of 1\% 12: 61:0 30 DAS + Foliar spray of 1\% 13:0:45 on 45 DAS (Fig.7). Increased grain production obtained in this treatment combination resulted in increased net income and B: C ratio. Higher grain productivity and lesser cost of cultivation due to saving in fertilizer resulted in increased net income and B: C ratio. Similar findings in blackgram were reported by Jahid Ahmad et al., (2019) and Sakthi et al., (2020).

Table 3. Effect of foliar nutrition on economics of rice fallow blackgram

\begin{tabular}{|c|c|c|c|c|c|}
\hline T.no. & Treatments & $\begin{array}{c}\text { Cost of * } \\
\text { cultivation } \\
\left(₹ \mathrm{ha}^{-1}\right)\end{array}$ & $\begin{array}{l}\text { Gross* } \\
\text { return ( } \\
\left.₹ h^{-1}\right)\end{array}$ & $\begin{array}{l}\text { Net* } \\
\text { return ( } \\
\left.₹ \text { hal }^{1}\right)\end{array}$ & $\begin{array}{l}\text { B:C* } \\
\text { Ratio }\end{array}$ \\
\hline T1 & Control & 9450 & 26791 & 17341 & 1.83 \\
\hline $\mathrm{T} 2$ & Foliar spray of $0.5 \% 19: 19: 19$ on 15,30 and 45 DAS & 11475 & 35101 & 23626 & 2.06 \\
\hline T3 & Foliar spray of $0.5 \% 12: 61: 0$ on 15,30 and 45 DAS & 11850 & 34045 & 22195 & 1.87 \\
\hline $\mathrm{T} 4$ & Foliar spray of $0.5 \% 13: 0: 45$ on 15,30 and 45 DAS & 11625 & 38828 & 27203 & 2.34 \\
\hline T5 & Foliar spray of $0.5 \% 19: 19: 19$ on 15 DAS + Foliar & 11650 & 47591 & 35941 & 3.09 \\
\hline
\end{tabular}




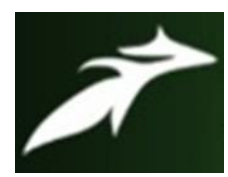

J.Sakthi et al, International Journal of Advances in Agricultural Science and Technology,

Vol.8 Issue.8, August-2021, pg. 110-114

ISSN: $2348-1358$

Impact Factor: 6.057

NAAS Rating: $\mathbf{3 . 7 7}$

\begin{tabular}{|c|l|c|c|c|c|}
\hline & $\begin{array}{l}\text { spray of 0.5\% 12: 61:0 30 DAS + Foliar spray of } \\
0.5 \% \text { 13:0:45 on 45 DAS }\end{array}$ & & & & \\
\hline T6 & Foliar spray of 1\% 19:19:19 on 15, 30 and 45 DAS & 12300 & 41913 & 29613 & 2.41 \\
\hline T7 & Foliar spray of 1\% 12: 61:0 on 15, 30 and 45 DAS & 13050 & 41075 & 28025 & 2.15 \\
\hline T8 & Foliar spray of 1\% 13:0:45 on 15, 30 and 45 DAS & 12600 & 45427 & 32827 & 2.61 \\
\hline T9 & $\begin{array}{l}\text { Foliar spray of 1\% 19:19:19 on 15 DAS + Foliar } \\
\text { spray of 1\% 12: 61:0 30 DAS + Foliar spray of } \\
1 \% \text { 13:0:45 on 45 DAS }\end{array}$ & 12650 & 53955 & 41305 & 3.27 \\
\hline
\end{tabular}

* Data not statistically analysed.

\section{References}

[1]. Balusamy, M. and N. Meyyazhagan. 2000. Foliar nutrition to pulse crop. Training manual on recent advances in pulses production technology, CASA, Tamil Nadu Agric. Univ., pp 113-115.

[2]. Jadhav.S.M., V.G. Takankhar, D. Raja And and C. S.Kumbhar. 2017. Influence of foliar nutrition on growth characters of black gram [Vigna mungo L.] under rainfed condition. Agric. Update, 12 (8): 201 -208 .

[3]. Jahid Ahmad, Murali K, Ali Ahmad, Amanullah Barak, MK Wasifhy and Ashuqullah Atif. 2019. Effect of water soluble fertilizer on growth and growth attributes of soybean [Glycine max (L.) Merrill]. International Journal of Advanced Education and Research, 4(2): 01 -04.

[4]. Sharifi, S. K., B. S.Lalitha, R.Qasimullah, G.K. Prajwal Kumar and S.S. Manjanagouda. 2018. Effect of Foliar Application of Water Soluble Fertilizer on Growth and Yield of Soybean (Glycine max L. Merrill). Int. J. Pure App. Biosci. 6 (5): 766-770.

[5]. Takankhar,V.G., P.N.Karanjikar and S.R.Bhoye. 2017. Effect of foliar nutrition on growth, yield and quality of chickpea (Cicer arietinumL.). Asian J. Soil Sci., 12 (2):296-299.

[6]. Sakthi.J, K.Ramya, M.Srinivasan, J. Sridhar and R.Kumar.2020. Foliar Application of Water Soluble Fertilizer on Growth and Yield of Rainfed Blackgram. Int. J. Adv. Agri. Sci. and Tech., 7(9): 1-8.

[7]. Sasikala. K., SNM Ramachandra Boopathi and P.Ashok. 2014. Evaluation of methods of sowing and post emergence herbicides for efficient weed control in zero till sown rice fallow black gram Vigna mungo L. Int. J. of Farm Sci., 4 (1): 81-91. 